\title{
The Potential of the Consumer Co-Operative as an Alternative to the Public-Private Partnership
}

\author{
Pasi Tuominen $^{1}$, Iiro Jussila ${ }^{1} \&$ Terhi Tuominen $^{1}$ \\ ${ }^{1}$ Lappeenranta University of Technology, School of Business, Lappeenranta, Finland \\ Correspondence: Pasi Tuominen, Lappeenranta University of Technology, School of Business, P.O. Box 20, \\ FIN-53851, Lappeenranta, Finland. E-mail: Pasi.Tuominen@lut.fi
}

Received: September 5, 2014

Accepted: October 17, 2014

Online Published: October 25, 2014

doi:10.5539/ibr.v7n11p174

URL: http://dx.doi.org/10.5539/ibr.v7n11p174

\begin{abstract}
During the past couple of decades, we have witnessed the increasing emergence of public-private partnerships (PPP). According to research in this area, the primary reason beyond the popularity of PPPs has been their ability to combine specific qualities of public and private sectors to the benefit of all. Even though it is not entirely clear that the expected benefits are achieved via PPPs, little of attention has been given to the alternative ways of achieving similar ends. In this paper we build on literatures on PPPs and on co-operatives in order to open discussion on the potential of consumer co-operatives as an alternative to PPPs in service provision. A few words on future research and policy issues are also offered.
\end{abstract}

Keywords: public-private-partnership, co-operative, service provision

\section{Introduction}

During the past couple of decades, public and private organizations have initiated collaborations, leading to increasing number of partnerships (Scharle, 2002). Growing academic attention has followed (e.g., Kapucu, 2006; Domberger \& Fernandez, 1999) and produced a loose definition according to which public-private partnerships (PPP) refer to formal collaboration arrangements between public and private sector organizations, which aim to satisfy public goals (Waring \& Currie, 2013). Since the introduction of the model, PPPs have been studied in various fields such as management (e.g., Domberger \& Fernandez, 1999), political science (e.g., Flinders, 2005), public administration (e.g., Hodge, 2004), health care research (e.g., Field \& Peck, 2003) and economics (e.g., Quiggin, 2005). The focus of this accumulating research has been for instance in the analysis of the underlying motives for PPPs as well as the potential costs, benefits, and risks.

According to Hodge and Greve (2007), the primary reason for the establishment of PPPs is the pursuit of creating mutual benefits for the public and private sectors. In other words, PPPs are expected to create synergistic dynamics drawing on the strengths and weaknesses of the partners. According to Vaillancourt-Rosenau (1999), however, evidence suggests that this is not always the case. Even though partnering may decrease costs in the short run, in many cases it does not deliver the expected superior performance in terms of equity, access, or democracy and rather than decrease the need for regulation, it appears to increase it. One likely reason behind this are the conflicting interests of the actors of the public and private sectors (Vaillancourt-Rosenau, 1999, Reijniers, 1994); whereas private rent-seeking companies are by definition mainly oriented towards profit, the interests of public sector actors may vary from legislation to issues such as favorable political opinion, minimization of risk and the realization of social goals. In the worst case both parties strive towards their own goals and the actual needs of the service users are more or less ignored.

Given the many challenges associated with PPP arrangements as it comes to reaching their ultimate goals (more efficient, but community controlled service provision), in our view, alternative solutions deserve more academic attention. In this paper, we theoretically investigate the potential of consumer co-operatives as a substitute to PPP arrangements in societies' strategies to organize service provision. The definition of co-operatives by MacPherson (1995) indicate that co-operatives can be regarded as participatory autonomous organizations, in which individuals have decided to voluntarily come together in order to fulfill their common economic and social needs by establishing a mutually owned, democratically-controlled and jointly used enterprise. Even though experiences of co-operative enterprises operating in the interface of private and public have been encouraging (Borgaza, 1996), to our knowledge academics interested in PPPs have not given much attention to co-operatives as a way of 
combining qualities of the private and the public. What makes this even more surprising is that co-operatives are typically referred to as the "third way" (e.g., Birchall, 1996) and the potential of consumer ownership of traditional public utilities, such as water utilities (Mori, 2013; Birchall, 2002; Morse, 2000), have been discussed in extant co-operative literature. With our work, we wish to take this thought further in the context of PPPs. To be more precise, the purpose of our work is to raise ideas and questions for future research, while also serving public debate on strategies of service provision.

We start with a discussion on the nature of PPPs and consumers' co-operative arrangements, highlighting the idea that in a broad sense, they aim at similar ends - combining the qualities of the private and the public in the provision of services. Analyzing the interests and orientations of public and private sector actors and their implication to service provision as well as the control mechanisms needed in smooth collaboration between the partners, we discuss the problems often associated with PPPs and introduce the potential of the consumer co-operative -model (to be seen) as a viable alternative to PPPs. Finally, after summarizing our work, we discuss its utility to future research and practice.

\section{Public-Private Partnerships and Co-Operatives}

Hodge \& Greve (2007) maintain that "PPPs are hailed as the main alternative to contracting out and privatization, and thus they are seen as a qualitative jump ahead in the effort to combine the strong sides of the public sector and the private sector." (p. 545). At best, the public sector in general draws attention to considerations of public interest, stewardship and solidarity and is therefore better in issues such as ensuring equity, continuity and stability of services (Vaillancourt-Rosenau, 1999). However, it is often considered that governments do not have in-house knowledge on how to deliver many types of public goods and services in the most cost-effective way and when this is the case, they need to engage partners who have the necessary expertise, knowhow and managerial adeptness (Forrer, Kee, Newcomer \& Boyer, 2010). It is expected that private sector actors are more creative, innovative, dynamic (adapt more easily and faster to the changes and abandon unsuccessfull activities) and efficient and, therefore, outperform public sector actors when it comes to executing economic tasks (Vaillancourt-Rosenau, 1999). That is, both the public and private sectors have specific qualities and if these are combined, the end result should be better for both parties.

The combination of private and public qualities, however, sets requirements on the partners. It is maintained that participants from each sector should internalize, adopt the principles and different view points defined by their counterparts (Linder, 1999,). That means government actors thinking and behaving like entrepreneurs and business actors embracing public interest considerations as well as expecting greater public accountability (Linder, 1999). This is not easily accomplished given the differences typically existing in the intellectual framings and motivations between the two sectors.

A review of co-operative literature (e.g., Pestoff, 1991, 1992; Spear, 2004) indicates that co-operatives offer the same quality that PPPs are hailed for. What this means in respect to combining the qualities of the private and the public is that while the business is run efficiently based on the (technological) needs and demands of the market, public (social) accountability is secured through democratic governance. Further, it seems that in consumer co-operatives the business and community systems (and identities) co-exists and interact quite naturally as they are both an outgrowth of the consumers' needs and aspirations. In the following we will discuss these features of consumer co-operation in relation to the identified challenges of PPP arrangements in more detail.

\subsection{Whose Interests Are Being Served?}

Public-private partnerships have emerged, since they are seen as offering substantial benefits as compared to entirely public service provision (Bloomfield, 2006). It is believed that moving the provision of services towards the private sector will result (via market mechanisms) in improved service quality and cost savings. From the government perspective PPPs have therefore been a means to avoid up-front capital expenditure and harness private sector efficiencies (Barlow, Roehrich, \& Wright, 2013). From the private business point of view PPPs have been a way to strengthen the overall role of private business in the society and to access new markets (e.g., Quiggin, 2005) with the expectancy of returns on investments in those markets (Barlow et al., 2013).

Considering the features of the private sector, it is argued that market forces may not always enhance the necessary and needed production of goods and services (Defeuilley, 1999). That is, private sector companies have obligations to investors (the proprietors) taking precedence over the desires of customers (Vaillancourt-Rosenau, 1999). As an example, Birchall (2002) reports a case from the UK, where private monopolies of water supply made excessive profits, while consumers at the same time were suffering companies' inability to reach the performance targets, in one case culminating on a disastrous supply failure due to the failure to repair and maintain the infrastructure. This example illustrates the need to secure adequate service provision with regulation, when the 
public sector actors are partnering with private firms. We will return to this issue later on.

A serious problem hindering the adequate service provision via PPP is also the so called cream skimming. Vaillancourt-Rosenau (1999) uses the examples of health insurers and mail delivery at rural areas; in the first case the incentives to avoid the sickest are significant and in the latter the taxpayers end up subsidizing the cost of regular mail service to these areas, which typically cannot be served at a profit and are therefore neglected by the private sector. Thus, shifting costs of serving the less profitable markets to public sector partner is an effective way to reduce risk for the private firm and in some cases the partnership largely consists of the governments payments to private operators for the market in which profits are unlikely (Sparer, 1999), increasing both the private partner's profits and the fiscal responsibility of the public sector (Vaillancourt-Rosenau, 1999). Thus, it is highly questionable whether this kind of operation results in any savings or improvements of service to their users.

However, public partners are not immune to pressures that may cause compromising service either; for example, they are under pressure to reduce costs for a variety of reasons. Vaillancourt-Rosenau (1999) maintains that "if partnerships emphasize cost reduction or profit maximization at the price of significant quality compromises, vulnerable populations may not be able to respond appropriately and aggressively" (16-17), residents of a nursing home being an example.

In addition to the questions regarding the quality and availability of services to certain communities, also their permanence is important. Even if private companies often seek long-term contracts with public actors, profit seeking companies do have and are willing to use the option of leaving and concentrating their resources to more favorable markets (Obermann, 1999). The same challenge may arise also when PPPs are concerned. That is, profit maximizing entities are unlikely to have the continuous service of public interest as their priority. From the perspective of a local community similar risks may also be associated with the behavior of the government (as a party to PPPs). In their search for cost cuts governments may leave local communities without access to nearby services. This is a serious threat to consumers (citizens) whose interest to services arises, as Mori (2013) put it, from being an inhabitant of a certain community.

As compared to PPPs, co-operatives could be a viable solution to the proponents of public services. According to Pestoff (1992), they argue that social services need to be produced by the state or municipalities or municipal actors and thus, should not be opened to rent-seeking interests of business enterprises. On the other hand, co-operatives could be a viable solution to the proponents of private services as well, who believe, according to Pestoff (1992), that governmental monopoly means (without exception) inefficiency in operation. In the economic sense, co-operatives are private, specialized units acting on the market. Thereby, they may rise above public service provision in their efficiency and quality. On the other hand, co-operatives are not for-profit organizations in the sense of shareholder capitalism (Michelsen, 1994). Instead, they aim at creating benefits for their members through co-operation. In many markets, consumer co-operatives have been known for their customer-centric innovativeness and drive for service improvements (Uski, Jussila, \& Saksa, 2007). After all, one of their primary tasks is to be providers of best quality in the market (Borgen, 2004). Although a co-operative has to be profitable in order to survive, it does not have to pay returns to investors (Mills, 2008). That is, co-operatives may operate in those fields and markets where their presence is needed and where social goals are equally important to economic goals. They also may remain in the business as long as they can cover the costs of operation (Fulton \& Hammond-Ketilson, 1992). In other words, with consumer co-operatives the community faces less risk of the service provider withdrawing. As put by Morse (2000), present and future consumers are likely to be better attended by their own co-operative seeking to maximize service than by an investor-owned utility aiming to maximize profits.

\subsection{Control Mechanisms Needed to Secure Adequate Service Provision}

From the community perspective PPPs are typically seen as safe way to provide services, since in these arrangements the public maintains its ability to control those markets through their representatives in public administration (Field \& Peck, 2003). In other words, PPPs are not privatized business models in which there occurs transformation of ownership from public to private sector. Instead, as Gerrard (2001) argues, PPPs are based on a business relationship that is constrained contractually rather than by market forces or the intervention of a statutory regulator. However, as discussed above, it is widely accepted that PPPs do not come without challenges that may in the long-run undermine the expected benefits (Bloomfield, 2006). It is argued that in order to receive the theoretical benefits of PPPs, many local governments will need expertise to protect public interests as aggressively as their counterparts in the private sector are working to protect the interests of companies seeking contracts from local government (Bloomfield, 2006). There is a lot of contracting and much of it begins from very different points of departure. Further, for example difficulties in effectively monitoring decisions regarding patient 
care in the private sector can actually increase costs even as compared to public service provision. On the other hand, Domberger and Fernandez (1999) argue that PPPs may be difficult to sustain also for private firms because they must allow some additional costs of doing business with government (e.g., costs of managing the relationship).

Given the challenges presented above, accountability in PPPs becomes an important question, requiring "the creation of proper safeguards to ensure that public services are not compromised for the sake of private profits" (Forrer et al., 2010: 477). The idea is that a proper design of a PPP and the incentives guiding the partners will then provide mutuality to the partnership. However, Vaillancourt-Rosenau (1999) reminds us that abuse is possible from both public and private providers and, therefore, issues such as equity of treatment and fair access to services are never certain. Thus, even if tangible economic benefits would accrue to both the public and private partners, there is no guarantee that the public interest is well served and "partnering cannot be defined as a success if it results in lower quality of public policy services, the need for more government oversight, and the need for expensive monitoring, even if it appears to reduce costs" (Vaillancourt-Rosenau, 1999, p. 18).

In our view, many of the above mentioned challenges could be overcome by using a consumer co-operative instead of a PPP. Already the starting point of consumer co-operation (member needs instead of shareholder value or the varying interests of public actors) to great extent speaks to equity of treatment and fair access to services without public control. As Spear (2000) maintains, co-operatives clearly exist mainly to serve their members. In more detail, this purpose of co-operatives is implemented through co-operative values and principles which can decrease the inequalities and disadvantages amongst members (Spear, 2000). It is simply not conceivable that the members of a co-operative would exploit themselves through monopoly pricing. This is because the consumers themselves control the service providers; the managers and the personnel of the co-operative. If the co-operative runs a profit, the consumers will share that profit or invest it in order to create future member benefits. (Morse, 2000) Noteworthy, user control may be very efficient - even more efficient than the control of investors over their corporation. This is because agency costs of user-ownership (i.e., that involves an intimate patronage relationship) may be significantly lower than those of investor-ownership (Peterson \& Anderson, 1996).

Noteworthy, the nature of co-operatives as non-governmental organizations (Normark, 1996) may make co-operatives more attractive to the proponents of private services, as compared to a partly government controlled PPP. One of the core principles of co-operation is to gain and maintain independence from the government. What this means is that the community organizes and controls the service provision itself (Tuominen, Jussila, \& Kojonen, 2009), without much need to active participation of public actors. While in a PPP a private organization takes responsibility for service provision for a given project being accountable to the community's representatives in a public organization (e.g., Reijniers, 1994), in the co-operative context the co-operative organization (managers and personnel) is responsible for service provision being accountable to governing bodies of the co-operative; the board and potential representative bodies consisting of service users themselves. In this way, co-operatives are capable of providing individuals more influence and control over the services - which other organization forms might not provide (Pestoff, 1999).

What should make co-operatives more attractive to the proponents of public services, as compared to an arrangement where the private partner is an investor-owned company, is that in co-operatives the focus is in actually delivering the services they are established for. Thereby, the public actors can consider that part of the environment as being taken care of - and will be of their concern merely in terms of infrastructure requirements.

\section{Discussion}

Consumer co-operatives have the potential to be considered as viable alternatives to public-private partnership (PPP) in the provision of a variety of services, since they can combine the qualities of the private and the public in a way that PPPs cannot. First, consumer co-operatives are actors of market economy that follow the traditional purpose of business in market economies: efficient (competitive) provision of services to the people in need. In other words, consumer co-operatives are less likely to suffer from the inefficiencies associated with public service provision. In fact, the participation of the owners themselves in service provision (as users and beneficiaries) is supposed to promote efficiency. Second, the strategies of consumer co-operatives will not be based on the quest for maximum profit and, thereby, there is no cream skimming. Following the principle of solidarity, co-operatives are in fact aimed at fixing inequalities of the market. In other words, using the power of co-operation, they attempt to secure the provision of and access to services in areas where both the private and public sector actors and their partnerships might lack interest in doing so.

Governance is another aspect speaking for the viability of consumer co-operatives as alternatives. As the interests of the partners in PPPs are typically in conflict, there is a lot of contracting. The idea is that private actors are made 
accountable to the government or municipal officials. Besides this, there is always the obligation that the service providers have for their shareholders. In other words, there are in fact three parties that may have very different interests in the company. In consumer co-operatives, such a conflict of interest does not exist. This is because the user, owner, and controller are the same. That is, it is the members of the service using community who control the services as consumers of those services and as the owners and administrators of the service provider. The following figufe (Figure 1) attempts to capture the main points above.
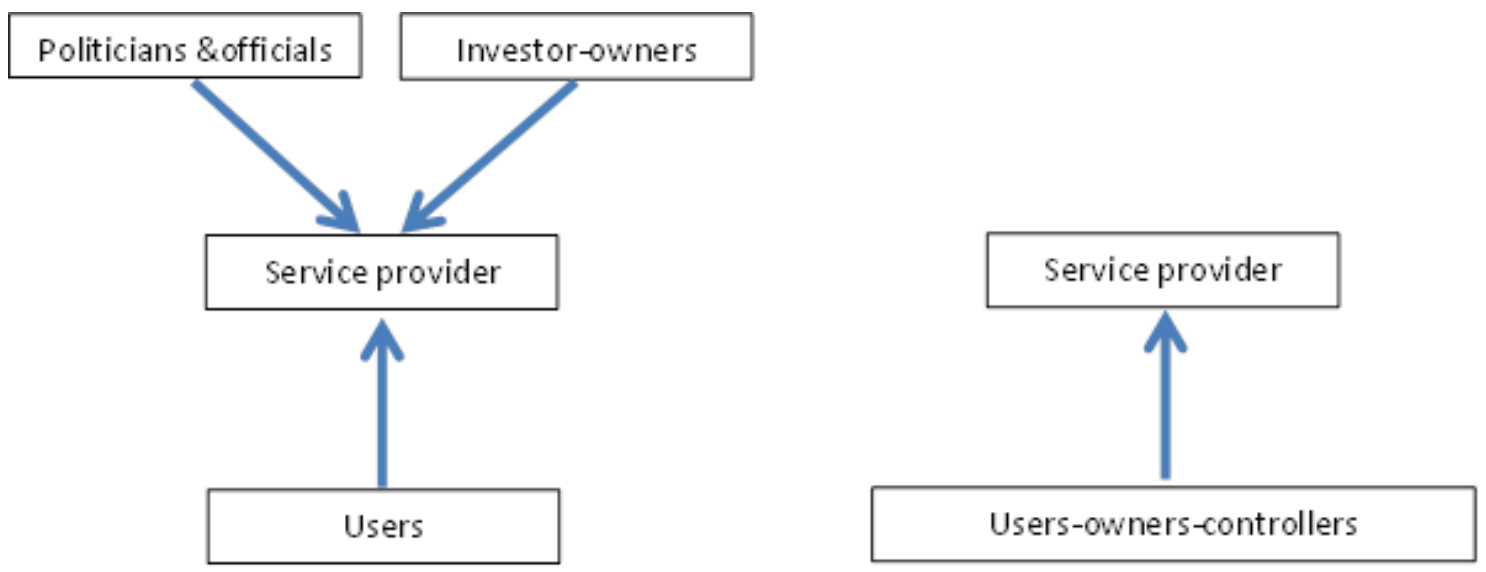

Figure 1. Governance differences between PPPs and consumer co-operatives

Consumer co-operatives are of course not without their own challenges. Some members may, for instance, be passive users or passive owners. Overall, the membership is not homogeneous. Thereby, the goals and control criteria of the co-operative is unlikely to be straight in line with the expectations of the entire membership. Nevertheless, as the co-operative is formed around somewhat similar service needs, this does not seem to be a dramatic challenge as compared to that of PPPs attempting to compromise between the interest of the service users, investor-owners, and the public actors monitoring the operation.

As it comes to future research, the potential of co-operatives as alternatives for PPP should be investigated using a variety of methods. Inductive qualitative research might serve to fine-grain our understanding of both PPPs and consumer co-operatives in comparative contexts and, thereby, generate also additional understanding on the potential strength and weaknesses of both models in different settings. Empirical comparative work could also be conducted quantitatively even if it will be difficult to find measures that could show one model being better than the other considering all the economic and social (also ethical and psychological) variables involved. Further, it should be interesting to find out if particular fields or societal contexts are favorable for one model or other.

Finally, let us offer a word on policy implications. The consumer co-operative can only be considered as a serious alternative to PPPs if the selection of the model is made based on what is the best alternative for the community, the people that are in need of and use the services. The motivations for the establishment of PPPs have not necessarily been in line with this idea. In fact, as put forward above, partnerships have been more or less motivated by private actors desire for growth and profit, while also public actors' primary interests may have been somewhat distorted as compared to those of the community. When such motivations are at play, the consumer co-operative is likely to remain as an under-utilized model.

\section{References}

Barlow, J., Roehrich, J., \& Wright, S. (2013). Europe sees mixed results from public-private partnerships for building and managing health care facilities and services. Health Affairs, 32, $146-154$. http://dx.doi.org/10.1377/hlthaff.2011.1223

Birchall, J. (1996). Neither public nor private: the Cooperative third way. Journal of Cooperative Studies, 85, 6875.

Birchall, J. (2002). Mutual, non-profit or public interest company? An evaluation of options for the ownership and control of water utilities. Annals of Public and Cooperative Economics, 73, 181-213. http://dx.doi.org/10.1111/1467-8292.00191 
Bloomfield, P. (2006). The challenging business of long-term public-private partnership: reflections on local experience. Public Administration Review, 600-411. http://dx.doi.org/10.1111/j.1540-6210.2006.00597.x

Borgen, S. (2004). Rethinking incentive problems in cooperative organizations. Journal of Socio-Economics, 33, 383-393. http://dx.doi.org/10.1016/S1053-5357(04)00049-6

Borzaga, C. (1996). Stakeholder cooperatives in European welfare. Soundings, 4, 203-211.

Domberger, S., \& Fernandez, P. (1999). Public-private partnerships for service delivery. Business Strategy Review, 10, 29-39. http://dx.doi.org/10.1111/1467-8616.00117

Field, J., \& Peck, E. (2003). Public-private partnerships in healthcare: the managers' perspective. Health and Social Care in the Community, 11, 494-501. http://dx.doi.org/10.1046/j.1365-2524.2003.00455.x

Flinders, M. (2005). The politics of public-private partnerships. British Journal of Politics \& International Relations, 7, 215-239. http://dx.doi.org/10.1111/j.1467-856X.2004.00161.x

Forrer, J., Kee, J. E., Newcomer, K. E., \& Boyer, E. (2010). Public-private partnerships and the public accountability question. Public Administration Review, 7, 475-484. http://dx.doi.org/10.1111/j.1540-6210.2010.02161.x

Fulton, M., \& Hammond-Ketilson, L. (1992). The Role of Cooperatives in Communities: Examples from Saskatchewan. Journal of Agricultural Cooperation, 7, 15-42.

Gerrard, M. B. (2001). Public-private partnerships. Finance \& Development, 38, 48-51.

Hodge, G. A. (2004). The risky business of public-private partnerships. Australian Journal of Public Administration, 63, 37-49. http://dx.doi.org/10.1111/j.1467-8500.2004.00400.x

Hodge, G. A., \& Greve, C. (2007). Public-private partnerships: an international performance review. Public Administration Review, 67, 545-558. http://dx.doi.org/10.1111/j.1540-6210.2007.00736.x

Kapucu, N. (2006). Public-nonprofit partnerships for collective action in dynamic contexts of emergencies. Public Administration, 84, 205-220. http://dx.doi.org/10.1111/j.0033-3298.2006.00500.x

Linder, S. H. (1999). Coming to terms with the public-private partnership. The American Behavioral Scientist, 43, 35-51. http://dx.doi.org/10.1177/00027649921955146

MacPherson, I. (1995). Co-operative Principles for the 21 st Century. ICA, Geneva.

Michelsen, J. (1994). The rationales of cooperative organizations. Some suggestions from Scandinavia. Annals of Public and Cooperative Economics, 65, 13-34. http://dx.doi.org/10.1111/j.1467-8292.1994.tb01504.x

Mills, C. (2008). Do large membership-based businesses have a future in the twenty first century? Some reflections on UK retail co-operative societies. Journal of Co-operative Studies, 41, 17-29.

Mori, P. A. (2013). Customer ownership of public utilities: new wine in old bottles. Journal of Entrepreneurial and Organizational Diversity, 2, 54-74. http://dx.doi.org/10.5947/jeod.2013.004

Morse, L. B. (2000). A case for water utilities as cooperatives and the UK experience. Annals of Public and Cooperative Economics, 71, 467-495. http://dx.doi.org/10.1111/1467-8292.00149

Normark, P. (1996). A role for cooperatives in the market economy. Annals of Public and Cooperative Economics, 67, 429-439. http://dx.doi.org/10.1111/j.1467-8292.1996.tb01914.x

Obermann, G. (1999). Sector-specific regulation from a public choice perspective with regard to the supple of services of public interest. Annals of Public and Cooperative Economics, 70, 195-211.

Pestoff, V. (1991). Co-operatives between markets and politics. Frankfurt: Campus.

Pestoff, V. (1992). Third sector and co-operative services - an alternative to privatization. Journal of Consumer Policy, 15, 21-45. http://dx.doi.org/10.1007/BF01016352

Pestoff, V. A. (1999). The future of consumer co-operatives in post-industrial societies? Journal of Co-operative Studies, 32, 208-219.

Peterson, H. C., \& Anderson, B. L. (1996). Cooperative strategy: theory and practice. Agribusiness, 12, 371-383. http://dx.doi.org/10.1002/(SICI)1520-6297(199607/08)12:4\%3C371::AID-AGR7\%3E3.0.CO;2-W

Quiggin, J. (2005). Policy forum: financing public infrastructure: public-private partnerships: options for improved risk allocation. The Australian Economic Review, 38, 445-450. 
http://dx.doi.org/10.1111/j.1467-8462.2005.00388.x

Reijniers, J. J. A. M. (1994). Organization of public-private partnership projects: The timely prevention of pitfalls. $\begin{array}{lllll}\text { International Journal of Project } & \text { Management, } & 12,\end{array}$ http://dx.doi.org/10.1016/0263-7863(94)90028-0

Scharle, P. (2002). Public-private partnership (PPP) as a social game. Innovation: The European Journal of Social Science Research, 15, 227-252. http://dx.doi.org/10.1080/1351161022000027630

Sparer, M. S. (1999). Myths and misunderstandings: health policy, the devolution revolution, and the push for privatization. American Behavioral Scientist, 43, 138-154. http://dx.doi.org/10.1177/00027649921955209

Spear, R. (2000). The co-operative advantage. Annals of Public and Cooperative Economics, 71, 507-523. http://dx.doi.org/10.1111/1467-8292.00151

Spear, R. (2004). Governance in democratic member-based organizations. Annals of Public and Cooperative Economics, 75, 33-59.

Tuominen, P., Jussila, I., \& Kojonen, S. (2009). Overcoming challenges to governance of consumer co-operation: Analysing reports of key representatives. International Journal of Co-operative Management, 4, $22-35$.

Uski, T., Jussila, I., \& Saksa, J. M. (2007). Regional retail co-operation: a strategic network perspective on a customer-owned organization. Journal of Co-operative Studies, 40, 18-29.

Vaillancourt-Rosenau, P. (1999). Introduction: The strengths and weaknesses of public-private policy partnerships. American Behavioral Scientist, 43, 10-34. http://dx.doi.org/10.1177/0002764299043001002

Waring, J., \& Currie, G. (2013). A contingent approach to the organization and management of public-private partnerships: an empirical study of English health care. Public Administration Review, 73, 313-326. http://dx.doi.org/10.1111/puar.12020

\section{Copyrights}

Copyright for this article is retained by the author(s), with first publication rights granted to the journal.

This is an open-access article distributed under the terms and conditions of the Creative Commons Attribution license (http://creativecommons.org/licenses/by/3.0/). 